\title{
33
}

\section{Voluntary Voting for Referendums in Australia: Old Wine, New Bottle}

\section{Graeme Orr ${ }^{1}$}

Voter turnout: to compel or not to compel? The question of compulsion in elections has been a perennial in Australia. In the 1960s Professor Joan Rydon said, in opposition to compulsory voting, that where 'the apathetic and ill-informed are forced to the polls by law, it is even more likely that the "scum and dregs" of political life will decide who is to govern the country'. Affirming compulsory voting's hoary status as 'contentious', recent years have witnessed failed attempts to argue that it is unconstitutional, ${ }^{3}$ and to legislatively reverse it. ${ }^{4}$

Rydon and the libertarians have not won the day. Compulsory voting - introduced to this country in stages from 1915 - remains the law of the land. Curiously, compulsion first entered at a national level not via elections, but via a kind of referendum, the first conscription plebiscite

\footnotetext{
1 Professor, Law School, University of Queensland.

2 Joan Rydon, 'The Electorate' in John Wilkes (ed), Forces in Australian Politics (Angus \& Robertson, 1963) 184.

3 Holmdahl v AEC (No 2) [2012] SASFC 110. See Anne Twomey, 'Compulsory Voting in a Representative Democracy: Choice, Compulsion and the Maximisation of Participation in Australian Elections' (2014) 13 Oxford University Commonwealth Law Journal 283.

4 Josh Butler, 'David Leyonhjelm Proposes Abolishing Compulsory Voting', Huffington Post, 2 March 2016 (Leyonhjelm is a libertarian senator).
} 
during World War I. ${ }^{5}$ As long as the major parties support it, whether out of democratic principle or because it saves them the cost of 'getting out the vote', compulsion will be a fixture of Australian elections. Reinforcing Australia's reputation as a pragmatic, Benthamite society rather than a rights-oriented one, opinion polls reveal consistent, strong support for electoral compulsion. ${ }^{6}$

Such contented stasis, however, belies a ferment. All is far from well in electoral democracy across the 'advanced democracies'. Symptoms include increased electoral volatility and declining faith in representative government. We might argue about the causes - economic stagnation or social atomisation? We might even argue whether these are problems needing cures, or transitions with positive potential to free-up politics from the two-party system. But the signs are not good.

My argument here is that compulsion, an old wine, is desirable for elections. But it doesn't belong in the referendum bottle. Compulsion at elections makes sense because:

- Everyone has an interest in day-to-day governance.

- The promise of the ballot is to ensure those interests are heard, through regular elections. There is evidence that, over time, compulsion leads to greater turnout of marginalised groups and that this can generate more egalitarian policy as politicians need to consider a broader range of social interests. ${ }^{7}$

- The ultimate pragmatic purpose of elections, at least in Australia, is to turn over or recall governments and MPs. As tapestries for deliberation, elections are open-ended and cannot be reduced to 'education campaigns', as is the ideal in referendums. ${ }^{8}$

5 Compulsory Voting Act 1915 (Cth). In the end, plebiscites were held in 1916 and again in 1917 under voluntary voting. Earlier in 1915, compulsion had been introduced for Queensland elections: Elections Act 1915 (Qld) s 63.

6 Between 1998 and 2013, support for compulsory voting ranged from a low of 69.5 per cent in 2010 to a high of 76.7 per cent in 2007 (source, AES exit polls).

7 As postulated by Arend Lijphart, 'Unequal Participation: Democracy's Unresolved Dilemma' (1997) 91 American Political Science Review 1. For empirical support, see John M Carey and Yusaku Horiuchi, 'Compulsory Voting and Income Inequality' (2017) 59 Latin American Politics and Society 122, a study of effects in Latin America and studies cited there.

8 Graeme Orr, 'Deliberation and Electoral Law' (2013) 12 Election Law Journal 421. 
- Contrary to Rydon, but echoing the cliché that even a dog knows the difference between being tripped over and kicked, under-informed voters do not undermine the purposes of electoral democracy. Lowinformation electors act rationally when they adopt heuristics such as 'Are we better off than three years ago?' or 'Do I trust leader X more than Y?'

- As elections are secular rituals which help bind societies, there may be communitarian and symbolic reasons to compel turnout. ${ }^{9}$

These and other arguments about compulsion in elections are well assayed elsewhere. ${ }^{10}$ The novel - hence 'law reform' - part of this argument relates to referendums. So referendums will be our focus. In what follows I will briefly outline the reasoning behind changing referendum law to make voting voluntary. To concretise the issue I will also relate a case study, about the most recent constitutional referendum, held in Queensland in March 2016. It shows how compulsion can exacerbate manipulative referendum processes.

I will argue, first, that Australian referendums tend to be on matters of law, especially constitutional law. Constitutional law is meta-law. It is not reasonable to expect everyone to care, let alone have a sensible view about such issues. Second, compulsory voting at such referendums is a conservative, not egalitarian force, helping to stall constitutional amendment. And, finally, there are no 'legitimacy' reasons to compel mass turnout at referendums.

\section{The Argument against Compulsion at Referendums}

Tracking the summary above, there are three planks to the argument.

First, constitutional law is meta-law. It is unreasonable to expect, let alone demand, that all electors address themselves sensibly to such issues. Elites often respond to this simple insight by bemoaning ignorance of the law

9 Graeme Orr, Ritual and Rhythm in Electoral Systems: A Comparative Legal Account (RoutledgeAshgate, 2015).

10 For example, Jason Brennan and Lisa Hill, Compulsory Voting: For and Against (Cambridge University Press, 2014). Arguments for compulsion in elections are comprehensively made in a body of work by Lisa Hill. 
and calling for more 'education'. The road to 'Getting to Yes' is to be paved with more civics education and greater spending on public information before and during referendum campaigns. ${ }^{11}$

There is something valiant, but a little vain, in such calls. Public education on particular referendum proposals may be valuable. But there is a naïve presumption, emanating from a university- and often legallyeducated class, that because people like us find public law fascinating and fundamental, all people should. Combined with compulsory turnout, the approach seems to be that institutions and laws can not only lead horses to water, but make them drink it too.

The position might be different if Australia relied on citizens-initiated referendums (CIR) to legislate specific social or policy issues, as do some US jurisdictions. Clearly there are social issues, of such common concern or import, where it is not just reasonable but likely that most electors will have well-reflected, 'values' based responses. But the odd plebiscite on issues like daylight savings - or on marriage equality, as mooted for 2017 - aside, CIR is not part of our tradition. If we governed ourselves through CIR alongside electing representatives, then arguments for compulsion at elections might apply.

Second, compulsory voting at such referendums is a conservative, not egalitarian force. That is, in a stable and well-off jurisdiction like Australia, compulsion is a small-'c' conservative method. In election campaigns, outside times of electoral volatility, it tends to dampen swings against incumbents regardless of the party concerned. ${ }^{12}$

In referendums, however, it makes no sense to insist on a conservative method like compulsion. It gives a free-kick to 'No' campaigns to run a 'When in doubt, throw it out' campaign, ${ }^{13}$ of the sort Williams and Hume aptly characterise as 'Don't know? Vote "no"'. ${ }^{14}$ If the constitutional

11 House of Representatives Standing Committee on Legal and Constitutional Affairs, $A$ Time for Change: 'Yes'l 'No': Inquiry into the Machinery of Referendums (Parliament of Australia, 2009) Chs 4-5 illustrate this thinking.

12 I discuss the reasons for this in 'Compulsory Voting: Elections, Not Referendums' (2011) 18 Pandora's Box 19.

13 The 'When in doubt ...' slogan was a centerpiece of the anti-Republic campaign in 1999.

14 George Williams and David Hume, People Power: The History and Future of the Referendum in Australia (UNSW Press, 2010) 253. 
status quo requires protection, this should be explicit, say via some supermajority requirement. ${ }^{15}$ Such brakes on constitutional reform should not be introduced unintentionally via compulsion.

Australia suffers constitutional stasis, not constitutional recklessness. Removing compulsion would remove one unnecessary barrier to much needed constitutional modernisation. Former Chief Justice Mason identified 'ignorance of the Constitution, now a well-documented fact' as an inducement to 'no' cases. ${ }^{16}$

But lest it be thought that my conclusions are motivated by 'progressive' bias, I offer the following response. Any presumption that compulsion at Australian elections benefits parties of the left over parties of the right is unproven. Indeed, in its tendency to reinforce the status quo it may simply reinforce exogenous political advantages, such as Labor's at state level (dominated by concerns about service delivery) and the conservative Coalition's at national level (demarked by a focus on national security and public finance). When it comes to policy, history shows that the great waves of progressive reforms in the common law world happened in Australia under compulsion at roughly similar times as they occurred under voluntary voting in New Zealand and the UK. This implies that political culture is more likely to be determinative of policy outcomes than differences in the voting system.

Third, once it is appreciated that referendums are quite different beasts to elections, the claim that compulsory voting 'legitimises' outcomes unravels. Representative government directly impacts everybody's life, every day. Few referendum questions do. It is a category error - as well as an historical and structural misstatement - to assert that because 'constitutional changes can alter Australia's democratic structure, it can be argued that the duty to vote in referendums is greater than the duty to vote in ordinary elections'. ${ }^{17}$ Australia's Constitution is largely process oriented and focused on Commonwealth-state powers, without even an explicit separation of powers let alone a focus on democratic rights. As a result, far from embracing momentous questions, referendums have most often concerned attempts to enhance particular Commonwealth powers.

15 The double majority rule in the Constitution s 128 is such a rule.

16 Sir Anthony Mason, 'Towards 2001 - Minimalism, Monarchism or Metamorphism' (1995) 21

Monash University Law Review 1 at 7.

17 Williams and Hume, above n 14, 49. In similar (muddle-headed) vein, see Sir Isaac Isaacs, A Stepping Stone to Greater Freedom (1946) 8-9. 
Other referendums have been on issues of legal significance, but of relatively minor import to electors generally, like the 1977 vote on judges' retiring ages. Important machinery questions, on which all sides of politics agree need constitutional reform - such as the sclerotic restrictions on who can be an MP under s 44 of the Constitution - lie marooned like rusting vessels. It is feared that putting their reform to a referendum will encounter voter cynicism about the cost or importance of the question. Similar fears led to the abandonment of the long process to hold a referendum to constitutionally recognise local government. If referendum voting were not compulsory, the argument that 'it's not a bread and butter priority' would have less traction.

Of course a few referendums do profoundly implicate questions of identity, notably referendums about secession. ${ }^{18}$ The one true secession referendum, in Western Australia in 1933, was conducted under compulsory voting. ${ }^{19}$ But, as the very high turnout at the 1916 conscription plebiscite in Australia and the 2015 Scottish independence referendum demonstrated, ${ }^{20}$ the momentous nature of such unusual referendums ensures high participation without legal compulsion.

For their part, state constitutions are largely flexible. Whether a state holds a referendum depends on political strategies and the happenstance of what issues relating to the 'constitution or powers' of state governments and parliaments have been entrenched. Territory constitutions are not even autonomous: they are still merely acts of the Commonwealth Parliament.

\section{A. When referendums go wrong - Queensland 2016}

The most recent referendum on these shores was the March 2016 vote on whether to entrench fixed, four-year terms in Queensland's constitution. ${ }^{21}$ The proposal was supported by both major parties and three independents, representing 87 of 89 parliamentarians in Queensland's unicameral system. It was also supported by major business and union leaders. Against were the minor parties and various academics, civil libertarians, lawyers and commentators. ${ }^{22}$ The 'no' case was not, on the whole, against fixed terms.

18 Voting about new states or state boundaries is distinct from s 128 . Indeed such votes are really plebiscites as they are not mandated by the Constitution.

19 Secession Referendum Act 1932 (WA) s 5(2).

2082.8 per cent and 84.6 per cent of electors respectively.

21 Constitution (Fixed Term Parliament) Amendment Bill 2015 (Qld).

22 Disclosure: I assisted the 'No' case publicly in this referendum. 
Rather, it objected to longer terms without any compensating checks or balances in a state with no upper house, no proportional representation, no charter of rights and just one state-wide newspaper. Although the campaign was a Goliath vs David one, the referendum only succeeded 52.8 per cent to 47.2 per cent.

What makes this referendum of interest was its risible process. The Bill was passed in a day, on the final sitting before Christmas. The poll was called, at barely five weeks' notice, to coincide with local government election day. And the 'Yes' case consisted largely of appeals to authority (recommendations by party, business and union leaders) rather than more valid forms of argument.

Part of the gamble of the referendum lay in a hurried process with minimal public education. The only formal voter education was the early$20^{\text {th }}$ century mechanism of 1,000-word 'Yes' and 'No' pamphlets, delivered to households. Electoral Commission staff even reported electors turning up to cast their local government ballot, unaware a referendum was being held. ${ }^{23}$

At the heart of the problem with the process was the bundling of two related but separable issues into a single question. People were not asked whether they wanted 'fixed' terms, and/or 'longer terms'. If they had, the answer would have been clear. Fixed terms provide stability and depoliticise election dates, but shorter terms enhance democratic input and accountability. And so it was that polling, for a public sector union that supported longer terms, showed that a sizeable majority of citizens wanted fixed terms yet a similar majority wanted to keep shorter terms. Electors' democratic instincts and values were keen. But those who framed the question wanted longer terms above all, so an attractive option was bundled with an unattractive option to skew the outcome.

23 Graeme Orr and Samara Cassar, 'When Referendums Go Wrong - Queensland's 2016 Fixed FourYear Term Proposal' (2016) 31 Australasian Parliamentary Review 161, 165. 
How does this relate to compulsory voting at referendums? A proponent for compulsion might retort that this example shows the importance of a long lead-time and consultative discussion and information, to till the field of public consciousness. And of more debate about how questions are framed, and separated or bundled..$^{24}$ But here is the rub.

There was no need for a referendum on fixed terms. Only the length of the parliamentary term was entrenched in Queensland's constitution (and for good historical reason). Yet what amount of public education would it take to explain the nature of 'manner and form entrenchment' in state constitutional practice? Even MPs, highly literate political journalists and otherwise well-read law students were ignorant of the distinction between flexible and entrenched state constitutional issues. What chance regular citizens? On such fine points of constitutional procedure rested the fate of this referendum.

\section{Conclusion: Reform}

In public law, the dazzle or heft of constitutional issues usually gain more attention than the nitty-gritty of statutory and administrative law. ${ }^{25}$ This was the case until relatively recently in the law of politics. Unsurprisingly, it remains especially so in relation to constitutional reform. After all, the machinery of referendums is hardly as interesting as the principles and purposes informing referendums. Of more interest are substantive debates about reform, like the Republic, or Indigenous 'recognition'. Recently there has emerged a burgeoning literature on whether and how referendums might become more deliberatively rich democratic exercises. ${ }^{26}$ Intriguingly these deliberative concerns are folding back into machinery questions. ${ }^{27}$

24 Some US state constitutions insist that referendums and initiatives 'shall embrace but one subject'. In Queensland the issues were related but separable. They deserved two questions, albeit on the same ballot.

25 Graeme Orr, 'Teaching Public Law: Content, Context and Coherence' (2015) 25 Legal Education Review 299 at 307.

26 For example, Paul Kildea 'A Little More Conversation? Assessing the Capacity of Citizens to Deliberate About Constitutional Reform in Australia' (2013) 22 Griffith Law Review 291.

27 For example, Ron Levy, Deliberative Voting: Realising Constitutional Referendum Democracy' [2013] Public Law 555; Rodney Smith and Paul Kildea, 'The Challenge of Informed Voting at Constitutional Referendums' (2016) 39 University of New South Wales Law Journal 341. 
My argument is not about deliberation as such. Voluntary voting would likely affect deliberation for better and for worse. To be implemented seriously, voluntary voting at referendums would have to be accompanied by a rule that referendums not coincide with elections, where compulsion would remain. This would partly disentangle partisan politics from referendum campaigns.

There is also the potential that campaigns under voluntary voting may focus more on turning out the already committed than on 'educating' the broader electorate. If that is a risk at referendums, I would venture to suggest it will only arise in instances of 'big ticket' constitutional reform, where it will be mitigated by the fact that turnout will naturally be higher. In any event, the risk just gives us more reason to strengthen the nonpartisan, publicly funded cases at referendum time, as well as learn from overseas, especially UK, experience on the importance of limiting thirdparty campaigns at constitutional referendums.

My argument also diverges completely from arguments against compulsory voting on libertarian grounds (arguments that reached a bemusing height in an article titled 'It's an Evil Thing to Oblige People to Vote ${ }^{28}$ ). Rather, mine is an institutionalist position. Referendums in this country are proposals for a particular type of law reform, and it is neither reasonable nor fair to attempt to require people be concerned about such proposals.

With climate change bearing down upon us, it may not be kosher to perpetuate the metaphor of Australia being 'constitutionally speaking ... the frozen continent' ${ }^{29}$ But voluntary voting at referendums might just melt a little of that rigid ice. It would certainly avoid giving the status quo 'No' case a head-start with 'If in doubt, kick it out' slogans. As the Queensland case study showed, voluntary voting may also take some sting out of manipulative processes by those proposing referendum questions.

The reform advocated here is of the 'suck it and see' variety. Some will try to argue that constitutional reform is on a deeper or more fundamental plane than electing representatives. To which I would ask 'more fundamental

28 Derek Chong et al (2005-6) 21(4) Policy 10. For a refutation of the libertarian position, see Lisa Hill, 'On the Reasonableness of Compelling Citizens to "Vote": The Australian Case' (2002) Political Studies 80. As the scarequotes around 'Vote' in Hill's title imply, in any secret ballot the compulsion is not to vote, but to turn out: see Faderson v Bridger (1971) 126 CLR 271 at 272. It would be preferable if ballots said 'you do not have to record a valid vote', a la former Electoral Act 1985 (SA) s 85(2).

29 Geoffrey Sawer, Australian Federalism in the Courts (Melbourne University Press, 1967). 
to whom?' Most people live lives in the concrete present. The question of who will wield executive and legislative power in the coming term of government is a pressing question. Constitutional law may or may not indirectly matter to them, but it is too much to demand that everyone participate in its enactment. In any event, if constitutional legitimacy has to be grounded in maximum turnout it is ironic, to say the least, that the creation of a federal Australia was achieved through voluntary voting. ${ }^{30}$ That process, for all its racial and class flaws, is valorised today as a rare example of a nation born out of peaceful deliberation rather than violence or neo-colonial struggle. Today's struggle, in contrast, is not to give birth to a new constitution, but to modernise our creaky constitutional structures. Such legal questions require citizen voice and participation, but not mandatory turnout.

30 The data is captured in Glenn Rhodes, Votes for Australia: How Colonials Voted at the 1899-1900 Federation Referendums (CAPSM, Griffith University, 2002). 
This text is taken from New Directions for Law in Australia: Essays in Contemporary Law Reform, edited by Ron Levy, Molly O’Brien, Simon Rice, Pauline Ridge and Margaret Thornton, published 2017 by ANU Press, The Australian National University, Canberra, Australia. 